\title{
PENINGKATAN KUALITAS BIBIT NYAMPLUNG (Calophyllum inophyllum L.) DAN MALAPARI (Pongamia pinnata L.) DENGAN APLIKASI MIKORIZA DAN Trichoderma spp.
}

Quality improvement of nyamplung (Calophyllum inophyllum L.) and malapari (Pongamia pinnata L.) seedlings by Trichoderma spp. and mycorrhizal applications

\author{
Benyamin Dendang dan Aditya Hani \\ Balai Penelitian dan Pengembangan Teknologi Agroforestry \\ Jl. Ciamis - Banjar Km 4, Jawa Barat, Indonesia \\ email: beny_co76@yahoo.co.id
}

Tanggal diterima: 7 Desember 2017, Tanggal direvisi: 19 Desember 2017, Disetujui terbit: 30 Mei 2018

\begin{abstract}
Nyamplung and malapari are potential bioenergy crops on marginal land to be developed on the coastal land. The constraints of the coastal land is the limited water and soil nutrient. Input technology is needed in order to suceed the crop planting such as by using bio fertilizer. Mycorrhizae plays an essential role in helping plants to absorb phosphate and increase the resistance to drought. Trichoderma spp. involves in producing beneficial hormones for metabolism and helps break down organic matter. Utilization of biofertilizer is still rarely used as treatment in bioenergy plant seedlings. This study aimed to determine the quality of nyamplung and malapari seedlings after mycorrhizal and Trichoderma spp. application in the nursery. Experiments were arranged in a complete randomized block design (RCBD). The treatments of media include: soil as control $(T)$, soil + organic fertilizer with ratio of 3:1(TK), soil + organic fertilizer + mycorhizae $10 \mathrm{~g}($ TKM $)$, soil + organic fertilizer + Trichoderma spp. $10 \mathrm{~g}$ (TKT), soil + organic fertilizer + mycorrhizal $10 \mathrm{~g}+$ Trichoderma spp. $10 \mathrm{~g}$ (TC). The treatments were applied when the seedlings reached one month old. Biofertilizer was sown around seedling roots. Each treatment consisted of 50 samples and 3 replications so the total seedlings were 750 seedlings. The results showed that after 6 and 12 months, treatment in malapari with organic fertilizer + mikoriza + TC gained $67.5 \%$ taller and $427 \%$ larger on dry weight of leaf than the control, whereas in nyamplung seedlings, TC treatment resulted in better growth with diameter $8 \%$ larger, root length $78.56 \%$ longer, and total dry weight $7.88 \%$ heavier compared to control.
\end{abstract}

Keywords: biofuel, coastal land, bio fertilizer

\begin{abstract}
ABSTRAK
Nyamplung dan malapari merupakan tanaman penghasil bioenergi yang potensial untuk dikembangkan di lahan marginal. Salah satu kendala dalam pengembangan lahan pantai adalah ketersediaan air dan kesuburan tanah yang rendah. Teknologi untuk meningkatkan keberhasilan penanaman salah satunya dengan pemanfaatan pupuk hayati. Penelitian ini bertujuan untuk mengetahui pengaruh pemberian mikoriza dan Trichoderma spp. pada media pembibitan bibit malapari dan nyamplung di persemaian. Pengamatan menggunakan metode rancangan acak kelompok lengkap (RAKL). Rancangan penelitian perbedaan media tanam bibit yaitu: tanah sebagai kontrol $(\mathrm{T})$, tanah + pupuk organik perbandingan 3:1 (TK), tanah + pupuk organik + mikoriza perbandingan 3:1:10 gram per polybag (TKM), tanah + pupuk organik + Trichoderma spp. perbandingan 3:1:10 gram per polybag (TKT), tanah + pupuk organik + mikoriza $10 \mathrm{gr}+$ Trichoderma spp. 10 gr per polybag (TC). Aplikasi dilakukan pada saat bibit berumur 1 (satu) bulan dengan cara ditaburkan di sekitar perakaran bibit. Setiap perlakuan terdiri dari 50 sampel yang diulang 3 kali, sehingga jumlah bibit keseluruhan adalah 750 bibit. Hasil penelitian menunjukkan bahwa setelah 6 dan 12 bulan perlakuan, bibit malapari dengan perlakuan TC memiliki tinggi dan berat kering daun yang lebih besar (67,5\% dan 427\%) dibanding kontrol (tanah), sedangkan bibit nyamplung dengan perlakuan TC menghasilkan pertumbuhan lebih baik dengan kenaikan diameter $8 \%$, panjang akar 78,56\%, dan berat kering total 7,88\% dibandingkan kontrol (T).
\end{abstract}

Kata kunci: bioenergi, lahan pantai, pupuk hayati 


\section{PENDAHULUAN}

Salah satu program pemerintah saat ini adalah mengembangkan energi biofuel sebagai pengganti dari energi fosil yang ada saat ini. Bioenergi memiliki kelebihan salah satunya karena dapat diperbaharui sehingga pemanfaatannya dapat dirasakan dari generasi ke generasi serta lebih bersih dari emisi bahan pencemar dibanding energi biofuel (Sugiyono, 2005). Direktorat Jenderal Energi Baru (2014) menyebutkan bahwa pemerintah menargetkan pada tahun 2016 penggunaan energi biofuel sebesar $20 \%$ berupa biodisel. Sumber bahan baku biodisel yang berpeluang untuk dikembangkan adalah sawit, jarak pagar, kemiri sunan dan nyamplung.

Kementerian Lingkungan Hidup dan Kehutanan turut serta dalam mengembangkan tanaman penghasil bioenergi. Jenis tanaman yang dikembangkan yaitu nyamplung (Calophyllum inophyllum L.) dan malapari (Pongamia pinnata L). Nyamplung dan malapari mempunyai peluang untuk dikembangkan karena kedua jenis tersebut tidak bersaing dengan kebutuhan pangan seperti halnya minyak sawit. Selain itu, biji malapari dan nyamplung mempunyai rendemen yang cukup tinggi (27-39\%) dan 40-73\% (Dwitama, Nasib, Sitepu, Suandi, \& Simpen, 2016). Malapari dan nyamplung merupakan jenis penyusun hutan pantai. Secara alami tanaman tersebut tumbuh di sepanjang pantai yang dapat tumbuh optimal dari ketinggian 0 - $200 \mathrm{mdpl}$, dengan tanah liat berpasir, tanah berpasir dan tanah liat bergumpal-gumpal dengan kondisi masin dan alkalin (Danu \& Putri, 2013). Pemanfaatan kedua jenis tersebut masih terbatas untuk bahan bangunan, pembuatan kapal, tanaman obat maupun kayu bakar (Alimah, 2010; Hadi, 2009).

Tanaman bioenergi potensial untuk dikembangkan di lahan marginal, lahan kritis maupun lahan pantai sehingga selain tidak bersaing dengan tanaman pertanian juga sebagai bagian dari program rehabilitasi lahan. Salah satu kendala pada lahan tersebut adalah ketersediaan air serta kondisi suhu dan kelembaban yang ekstrim. Hal ini memerlukan masukan teknologi sehingga tanaman mempunyai adaptasi yang tinggi. Salah satu teknologi tersebut adalah pemanfaatan mikroba tanah seperti mikoriza yang membantu tanaman menyerap pospat dan ketahanan terhadap kekeringan serta Trichoderma spp. yang berperan dalam menghasilkan hormon dan pengurai bahan organik. Penyerapan unsur hara dapat ditingkatkan salah satunya apabila terdapat asosiasi antara akar tanaman sekunder dengan jamur tertentu (Elviati \& Siregar, 2010). Syamsuwida, Putri, Kurniaty, dan Aminah (2015) menyebutkan bahwa bibit malapari dapat tumbuh baik apabila diberi 2,5 gram mikoriza + 1 gram NPK. Penggunaan pupuk hayati dengan pupuk organik (kompos) perlu ditingkatkan sehingga dapat mengurangi ketergantungan terhadap pupuk kimia serta lebih ramah lingkungan.

Sinergisme antara mikoriza, Trichoderma spp. dan pupuk organik diharapkan dapat terbawa oleh tanaman pada saat dipindah ke lapangan sehingga pertumbuhan tanaman meningkat. Sari, Mardhiansyah, dan Sribudiani (2014) menyebutkan bahwa penggunaan mikoriza dan Trichoderma pada bibit meranti untuk penanaman di lahan gambut memberikan pengaruh positif terhadap pertumbuhan, sedangkan pada bibit jabon pemberian mikoriza dapat meningkatkan pertumbuhan semai pada media yang berasal dari limbah batubara (Tamin, 2016). Trichoderma terbukti mampu mengendalikan jamur ganoderma serta memacu pertumbuhan bibit sengon (Dendang \& Hani, 2014; Herliyana, Jamilah, Taniwiryono, \& Firmansyah, 2015). Tchameni et al. (2011) menyebutkan bahwa pemberian mikoriza dan Trichoderma secara bersamaan menghasilkan tinggi, berat basah tunas dan akar lebih besar dibandingkan bibit kakao tanpa perlakuan. Trichoderma bersama akar tanaman akan melepaskan hormon auxin, peptida, senyawa 
organik di tanah sekitar perakaran dan berbagai senyawa metabolisme aktif yang lain yang memacu perkembangan perakaran sehingga dapat meningkatkan serapan hara untuk meningkatkan pertumbuhan tanaman (LópezBucio, Pelagio-Flores, \& Herrera-Estrella, 2015). Pemanfaatan mikoriza, Trichoderma dan pupuk organik pada jenis tanaman penghasil bioenergi belum banyak dilakukan. Padahal pengembangan kedua jenis tersebut umumnya dilakukan pada lahan marginal yaitu pantai berpasir, sehingga bibit yang dipersiapkan harus mempunyai kualitas baik serta cepat beradaptasi dengan kondisi marginal. Penelitian ini bertujuan untuk mengetahui kualitas bibit nyamplung dan malapari yang diaplikasi dengan kompos, mikoriza dan Trichoderma spp. sampai umur 6 bulan di persemaian.

\section{METODE PENELITIAN}

\section{A. Waktu dan tempat}

Penelitian dilaksanakan mulai bulan Agustus 2015 sampai bulan Oktober 2016 di persemaian Balai Penelitian dan Pengembangan Teknologi Agroforestry.

\section{B. Bahan dan alat}

\section{Bahan}

Bahan yang digunakan adalah pupuk organik (kotoran kambing), Trichoderma spp. bentuk formula padat, konsentrasi yang digunakan sebanyak 25 gram (hasil Balai Penelitian Perkebunan Bogor); mikoriza yang digunakan adalah Cendawan Mikoriza Arbuskula (CMA) yang diperbanyak pada tanaman semusim dengan media zeolite selama tiga bulan. Spora yang menempel pada zeolite ditimbang sebanyak 10 gram untuk perlakuan; benih nyamplung; benih malapari; polybag; kompos dan tanah. Benih nyamplung dan malapari diperoleh dari hutan pantai Pangandaran dan Batukaras Kabupaten Pangandaran Jawa Barat.

\section{Alat}

Alat yang digunakan adalah: cangkul, penggaris, meteran, pengukur diameter (caliper), oven dan alat tulis.

\section{Metode penelitian}

Penelitian ini dilakukan dengan menggunakan Rancangan Acak Kelompok Lengkap (RAKL) dengan 4 macam perlakuan media dan 1 kontrol. Setiap perlakuan terdiri dari 50 sampel yang diulang sebanyak 3 ulangan sehingga jumlah bibit keseluruhan adalah 750 bibit. Mikoriza dan Trichoderma spp. diberikan sebelum penanaman.

Benih langsung dikecambahkan ke dalam polybag yang berisi media tanah ( $\mathrm{T}$ ); tanah + kompos perbandingan 3:1 (TK); tanah + kompos + mikoriza 10 gram (TKM); tanah + kompos + Trichoderma spp. 10 gr (TKT) dan tanah + kompos + mikoriza 10 gr + Trichoderma spp. $10 \mathrm{gr}$ (TC).

Pengukuran bibit dilakukan pada saat umur bibit 2, 4, 6 dan 12 bulan dengan parameter yang diukur meliputi tinggi, diameter, dan persen hidup. Pada saat bibit berumur 12 bulan dilakukan pengukuran panjang akar, jumlah daun, jumlah bintil akar dan biomassa tanaman (meliputi berat kering daun, akar, dan batang) dengan menggunakan sampel secara destructive sampling sebanyak 3 (tiga) bibit setiap perlakuan. Pengukuran biomassa tanaman diharapkan dapat memberikan hasil pertumbuhan secara lebih komprehensif, tidak hanya melalui tinggi dan diameter saja.

\section{Analisis data}

Data hasil pengamatan selanjutnya dianalisis menggunakan analisis keragaman untuk mengetahui perbedaan nyata antar perlakuan. Apabila terdapat perbedaan yang nyata antar perlakuan maka dilanjutkan dengan uji lanjut Duncan untuk mengetahui perlakuan yang terbaik. Kualitas bibit diketahui dari kekokohan bibit (Hendromono, 2003), rasio pucuk akar (Hendromono, 2003) dan indeks 
mutu bibit (Dickson, Leaf, \& Hosner, 1960) dengan rumus sebagai berikut:

Kekokohan bibit $(\mathrm{KB})=\frac{\text { tinggi }(\mathrm{cm})}{\operatorname{diameter}(\mathrm{mm})}$

Rasio pucuk akar $($ RPA $)=\frac{\text { berat kering pucuk }(\text { gram })}{\text { berat kering akar }(\text { gram })}$

Indeks mutu bibit $(\mathrm{IMB})=\frac{\mathrm{BKT}}{\mathrm{KB}+\mathrm{RPA}}$

dimana, $\mathrm{BKT}=$ Berat kering total, dihitung dari berat kering pucuk (gram) + berat kering akar (gram).
Nilai kekokohan bibit yang semakin tinggi menunjukkan bibit semakin baik. Rasio pucuk dan akar yang baik pada kisaran 2-5, sedangkan indeks mutu bibit yang baik mempunyai nilai $>0,09$ (Hendromono, 2003).

\section{HASIL DAN PEMBAHASAN}

\section{A. Pertumbuhan bibit}

Pertumbuhan tinggi dan diameter bibit nyamplung serta malapari disajikan pada Gambar 1 dan 2.

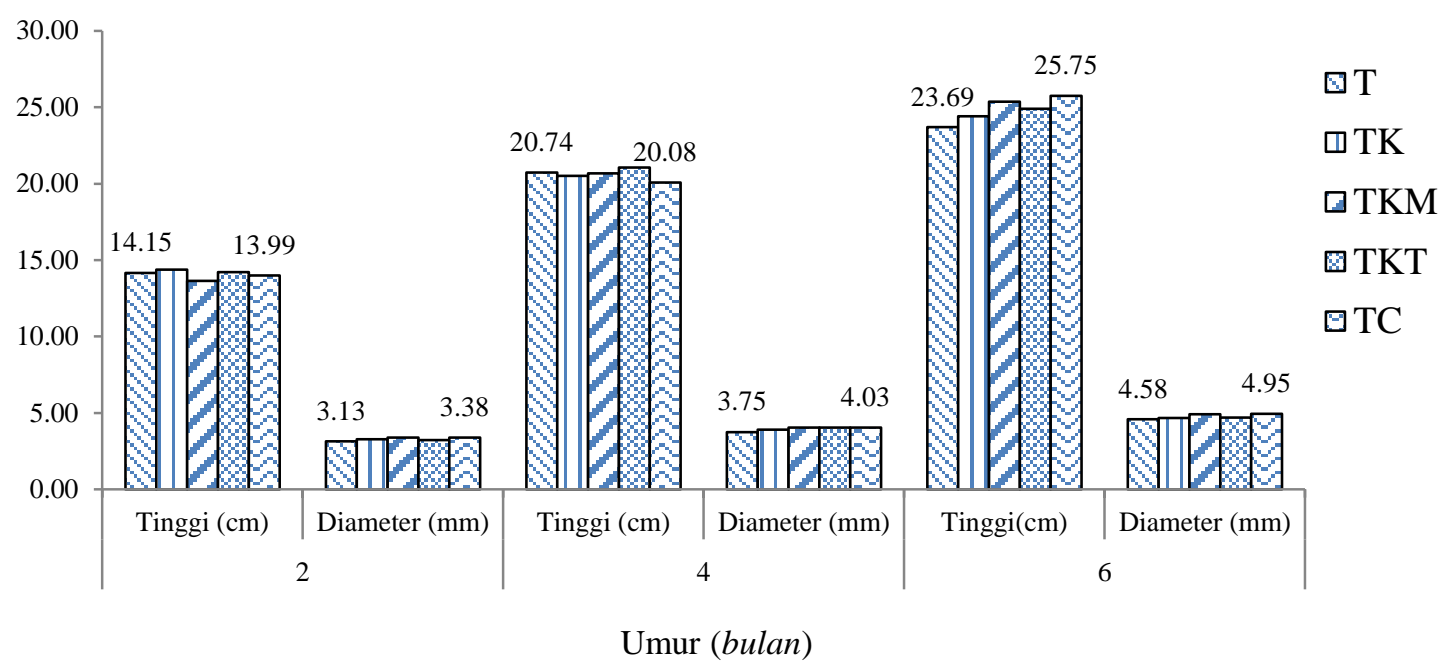

Keterangan: $\mathrm{T}=$ Tanah; $\mathrm{TK}=$ Tanah + Pupuk organik; TKM $=$ Tanah + Pupuk organik + Mikoriza; TKT $=$ Tanah + Pupuk organik + Trichoderma spp.; TC $=$ Tanah + Pupuk organik + Mikoriza + Trichoderma spp.

Gambar 1. Pertumbuhan bibit nyamplung di persemaian sampai dengan umur 6 bulan

Gambar 1 menunjukkan bahwa tinggi dan diameter bibit nyamplung semakin meningkat seiring bertambahnya umur. Bibit nyamplung sampai umur 4 bulan memiliki pertumbuhan yang relatif hampir sama, tinggi $\pm 20 \mathrm{~cm}$ dan diameter 3,75-4,03 mm. Suryawan (2014) menyebutkan bahwa bibit nyamplung di persemaian yang hanya menggunakan media tanah sampai umur tiga bulan menghasilkan tinggi dan diameter berturut-turut sebesar 20,7 $\mathrm{cm}$ dan 3,2 mm. Namun demikian, bibit nyamplung setelah berumur 6 bulan memiliki pertumbuhan yang berbeda antar perlakuan. Hal ini dimungkinkan karena pada umur tersebut kebutuhan unsur hara oleh bibit semakin meningkat, sedangkan ketersediaan unsur hara di dalam media tanah di polybag semakin menurun. Perlakuan campuran tanah + pupuk organik + Trichoderma spp. + mikoriza (TC) memberikan pertambahan tinggi dan diameter per bulan tertinggi dengan rata-rata $2,93 \mathrm{~cm}$ (tinggi) dan rata-rata $0,39 \mathrm{~mm}$ (diameter). Perlakuan pemberian TC memberikan pertambahan tinggi terbesar dikarenakan keberadaan pupuk organik, Trichoderma spp. dan mikoriza yang saling melengkapi untuk mendukung pertumbuhan tanaman. Trichoderma spp. yang berfungsi sebagai 
dekomposer segera mengurai pupuk organik yang tersedia sehingga lebih cepat dimanfaatkan oleh tanaman. Mikoriza dapat meningkatkan penyerapan phospor. Phospor berfungsi untuk perkembangan perakaran tanaman khususnya pada tanaman muda serta sebagai bahan mentah pembentukan protein (Purwati, 2013). Inokulasi mikoriza pada tanaman malapari dapat meningkatkan biomassa setelah cadangan makanan dalam kotiledon menurun atau 90 hari setelah aplikasi baru terlihat efek positif dari asosiasi akar dan mikoriza (Ramesh, Birajdar, Tanaji, \& Bhale, 2017).

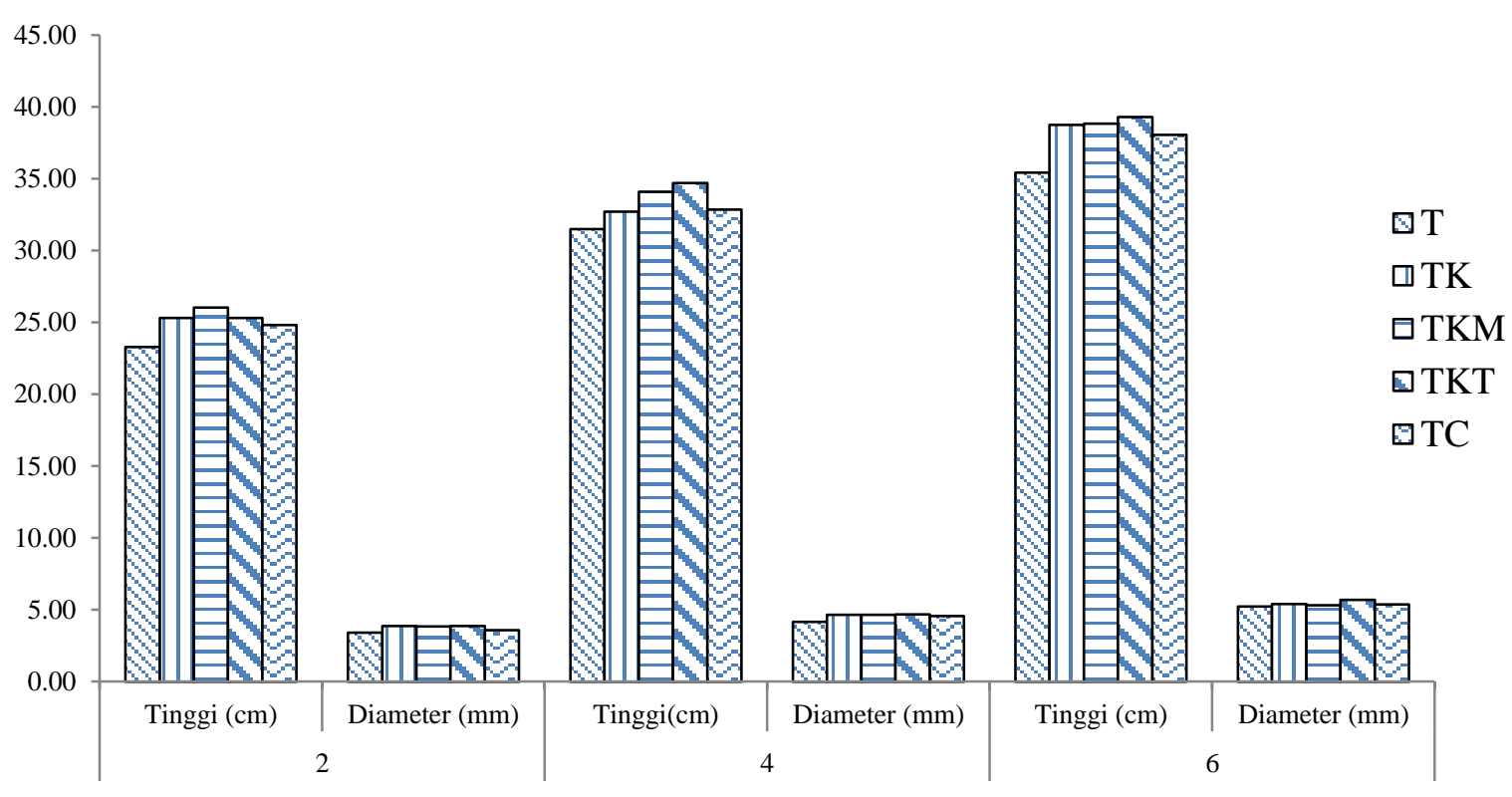

Umur (bulan)

Keterangan: $\mathrm{T}=$ Tanah; $\mathrm{TK}=$ Tanah + Pupuk organik; TKM $=$ Tanah + Pupuk organik + Mikoriza; $\mathrm{TKT}=$ Tanah + Pupuk organik + Trichoderma spp.; $\mathrm{TC}=$ Tanah + Pupuk organik + Mikoriza + Trichoderma spp.

Gambar 2. Pertumbuhan bibit malapari di persemaian sampai dengan umur 6 bulan

Gambar 2 menunjukkan bahwa tinggi dan diameter tanaman malapari semakin meningkat seiring bertambahnya umur. Sampai umur 6 bulan, perlakuan TKT menghasilkan pertumbuhan tercepat dengan pertambahan tinggi rata-rata $3,5 \mathrm{~cm}$ dan diameter rata-rata $0,45 \mathrm{~mm}$ per bulan. Perlakuan pemberian Trichoderma spp. memberikan pertambahan tinggi terbesar dikarenakan pada media tanaman di persemaian ketersediaan unsur hara yang berasal dari bahan organik masih mencukupi. Trichoderma spp. yang berfungsi sebagai dekomposer segera mengurai pupuk organik yang tersedia sehingga lebih cepat dimanfaatkan oleh tanaman. Kusuma (2016) menyebutkan bahwa enzim celobiohidrolase, endoglikonase dan glokosidase yang dihasilkan Trichoderma spp. mempercepat proses penguraian serta meningkatkan kualitas hasil dari pupuk organik. Hasil analisis keragaman pengaruh media tanam terhadap pertumbuhan bibit nyamplung dan malapari disajikan pada Tabel 1 .

Pertumbuhan bibit malapari pada umur 6 bulan tidak ada perbedaan yang nyata antar perlakuan (Tabel 1). Namun pada umur 12 bulan bibit malapari menunjukkan perbedaan nyata antar perlakuan pada parameter tinggi dan berat kering daun. Sedangkan bibit nyamplung memiliki perbedaan yang nyata antar perlakuan mulai umur 6 pada parameter diameter bibit dan pada umur 12 bulan pada parameter panjang akar, berat kering daun, berat kering batang dan total biomasa. 
Tabel 1. Hasil analisis keragaman pengaruh media tanam terhadap pertumbuhan bibit nyamplung dan malapari di persemaian

\begin{tabular}{|c|c|c|c|c|}
\hline Sumber variasi & $\begin{array}{c}\text { Derajat } \\
\text { bebas }\end{array}$ & $\begin{array}{l}\text { Kuadrat } \\
\text { Tengah }\end{array}$ & F hitung & Sig. \\
\hline \multicolumn{5}{|l|}{ Malapari (Pongamia pinnata L.) } \\
\hline \multicolumn{5}{|c|}{ Umur 6 bulan } \\
\hline Diameter & 4 & 16,35 & 2,29 & 0,059 \\
\hline Tinggi & 4 & 213,11 & 0,79 & 0,53 \\
\hline \multicolumn{5}{|c|}{ Umur 12 bulan } \\
\hline Diameter & 4 & 2,945 & 2,15 & 0,166 \\
\hline Tinggi & 4 & 252,15 & 5,28 & $0,022 *$ \\
\hline Panjang akar & 4 & 93,90 & 0,83 & 0,542 \\
\hline Jumlah daun & 4 & 14,43 & 1,21 & 0,378 \\
\hline Berat kering akar & 4 & 2,69 & 1,45 & 0,303 \\
\hline Berat kering daun & 4 & 3,81 & 3,90 & $0,048 *$ \\
\hline Berat kering batang & 4 & 2,48 & 1,58 & 0,271 \\
\hline Jumlah bintil akar & 4 & 33,60 & 1,32 & 0,340 \\
\hline Berat total biomasa & 4 & 23,94 & 2,03 & 0,181 \\
\hline \multicolumn{5}{|c|}{ Nyamplung (Calophyllum inophyllum L.) } \\
\hline \multicolumn{5}{|c|}{ Umur 6 bulan } \\
\hline Diameter & 4 & 3,33 & 3,04 & $0,017 *$ \\
\hline Tinggi & 4 & 57,02 & 2,03 & 0,088 \\
\hline \multicolumn{5}{|c|}{ Umur 12 bulan } \\
\hline Diameter & 4 & 1,90 & 2,54 & 0,122 \\
\hline Tinggi & 4 & 350,73 & 3,50 & 0,062 \\
\hline Panjang akar & 4 & 195,83 & 7,58 & $0,008 *$ \\
\hline Jumlah daun & 4 & 58,77 & 3,34 & 0,069 \\
\hline Berat kering akar & 4 & 9,64 & 3,78 & 0,052 \\
\hline Berat kering daun & 4 & 39,17 & 5,47 & $0,020 *$ \\
\hline Berat kering batang & 4 & 12,58 & 4,39 & $0,036^{*}$ \\
\hline Jumlah bintil akar & 4 & 2819,77 & 3,32 & 0,070 \\
\hline Berat total biomasa & 4 & 142,31 & 5,69 & $0,018 *$ \\
\hline
\end{tabular}

Keterangan: * berbeda nyata pada tingkat kepercayaan $95 \%$

Hasil uji lanjut Duncan pada perlakuan yang terbaik pada bibit malapari disajikan pada Tabel 2. Pertumbuhan tinggi dan berat kering daun bibit malapari terbesar ditunjukkan oleh perlakuan TC. Hal ini disebabkan pada usia 12 bulan unsur hara yang terkandung dalam ketiga perlakuan mampu memberikan efek positif untuk pertumbuhan tanaman. Pupuk organik berperan sebagai penyedia unsur hara dan perbaikan kondisi lingkungan untuk perkembangan jamur. Trichoderma spp. berperan dalam penguraian unsur $\mathrm{N}, \mathrm{P}$ dan $\mathrm{S}$ yang nantinya diserap oleh tanaman sedangkan mikoriza berperan dalam penyerapan unsur $\mathrm{P}$ dan menghasilkan asam-asam organik (Charisma, Rahayu, \& Isnawati, 2012). Unsur- unsur tersebut dimanfaatkan oleh tanaman dalam proses metabolisme untuk pertumbuhan.

Tabel 2. Hasil uji lanjut Duncan pertumbuhan malapari

\begin{tabular}{ccc}
\hline Perlakuan & $\begin{array}{c}\text { Tinggi } \\
(\mathrm{cm})\end{array}$ & $\begin{array}{c}\text { Berat Kering daun } \\
(\text { gram })\end{array}$ \\
\hline TC & $44,67 \mathrm{a}$ & $3,22 \mathrm{a}$ \\
TKM & $38,33 \mathrm{ab}$ & $1,58 \mathrm{ab}$ \\
TKT & $34,83 \mathrm{ab}$ & $1,08 \mathrm{~b}$ \\
T & $26,67 \mathrm{bc}$ & $0,61 \mathrm{~b}$ \\
TK & $21,67 \mathrm{c}$ & $0,39 \mathrm{~b}$ \\
\hline
\end{tabular}

\footnotetext{
Keterangan:

$\mathrm{T}=$ tanah,

$\mathrm{TK}=$ tanah+kompos

$\mathrm{TKM}=$ tanah+kompos+mikoriza

TKT $=$ tanah+kompos+Trichoderma spp.,

$\mathrm{TC}=$ tanah+kompos+mikoriza+ Trichoderma spp.
} 
Hasil uji lanjut Duncan pada perlakuan yang terbaik pada bibit nyamplung disajikan pada Tabel 3. Perlakuan TC menghasilkan diameter batang, panjang akar, berat kering daun, berat kering batang dan berat total biomassa nyamplung terbesar. Trichoderma spp. berperan dalam pengaturan siklus hara secara berkesinambungan dengan cara menyediakan hara yang diperlukan tanaman dan menyimpan hara yang belum diperlukan tanaman (Marbun, Yunasfi, \& Mulya, 2015). Keberadaan kompos selalu memberikan pengaruh yang positif karena mikoriza maupun Trichoderma spp. selalu berinteraksi positif dengan bahan organik (Nurbaity, Herdiyantoro, \& Mulyani, 2009). Hasil yang sama ditunjukkan pada percobaan oleh Arriagada, Aranda, Sampedro, Garcia-Romera, dan Ocampo (2009) yang menemukan bahwa pemberian Trichoderma spp. pada bibit Eucalyptus globulus dapat meningkatkan berat kering akar dan batang serta kandungan klorofil dalam daun, sedangkan mikoriza akan meningkatkan serapan phospor. Trichoderma spp. akan meningkatkan $\mathrm{pH}, \mathrm{C} / \mathrm{N}$ ratio, $\mathrm{N}$ dan $\mathrm{C}$ sehingga dapat meningkatkan produksi berat kering pada hasil akhir tanaman (Sajimin, Raharjo, Purwantari, \& Sutedi, 2007). Kompos mempunyai peran yang penting karena berfungsi sebagai media tumbuh sekaligus pembawa cendawan mikoriza maupun Trichoderma spp. (Suprapti, Santoso, Djarwanto, \& Turjaman, 2012). Pemberian kompos akan mengefektifkan kinerja Trichoderma spp. karena bahan organik yang tersedia sudah terurai menjadi selulosa dan hemi selulosa (Mahdiannoor, 2012). Mikoriza dan Trichoderma spp. dapat dikombinasikan karena dapat mempercepat pertumbuhan dan perkembangan tanaman serta menekan perkembangan penyakit melalui sistem perakaran (Latifah, Hendrival, \& Mihram, 2014).

Tabel 3. Hasil uji lanjut Duncan pada pertumbuhan tanaman nyamplung

\begin{tabular}{cccccc}
\hline Perlakuan & $\begin{array}{c}\text { Diameter umur 6 } \\
\text { bulan }(\mathrm{mm})\end{array}$ & $\begin{array}{c}\text { Panjang akar } \\
(\mathrm{cm})\end{array}$ & $\begin{array}{c}\text { Berat Kering } \\
\text { daun }(\mathrm{gram})\end{array}$ & $\begin{array}{c}\text { Berat Kering } \\
\text { batang }(\mathrm{gram})\end{array}$ & $\begin{array}{c}\text { Berat total biomassa/ } \\
\text { Total }(\text { gram })\end{array}$ \\
\hline TC & $4,95 \mathrm{a}$ & $41,66 \mathrm{a}$ & $10,19 \mathrm{a}$ & $6,79 \mathrm{a}$ & $22,41 \mathrm{a}$ \\
TKM & $4,90 \mathrm{ab}$ & $35,00 \mathrm{ab}$ & $11,28 \mathrm{a}$ & $7,13 \mathrm{a}$ & $21,90 \mathrm{a}$ \\
TKT & $4,69 \mathrm{bc}$ & $43,33 \mathrm{a}$ & $7,40 \mathrm{ab}$ & $4,22 \mathrm{ab}$ & $17,32 \mathrm{ab}$ \\
TK & $4,65 \mathrm{c}$ & $31,67 \mathrm{bc}$ & $3,97 \mathrm{~b}$ & $3,03 \mathrm{~b}$ & $9,19 \mathrm{~b}$ \\
T & $4,58 \mathrm{c}$ & $23,33 \mathrm{c}$ & $3,17 \mathrm{~b}$ & $2,82 \mathrm{~b}$ & $7,88 \mathrm{~b}$ \\
\hline
\end{tabular}

Keterangan: Angka diikuti huruf yang sama dalam kolom tidak berbeda nyata pada tingkat kepercayaan $95 \%$

Perlakuan TC memberikan hasil biomassa terbesar dengan dukungan sistem perakaran yang baik. Pertumbuhan akar distimulasi oleh adanya pupuk organik yang menghasilkan sifat fisik dan kimia tanah yang lebih baik (Roidah, 2013). Suplai nutrisi yang mencukupi dengan adanya pupuk organik serta penyerapan yang maksimal karena adanya Trichoderma spp. dan mikoriza menyediakan bahan untuk metabolisme tanaman yang optimal sehingga pertumbuhan vegetatif seperti akar, batang dan daun menjadi pesat.

\section{B. Kualitas bibit}

Salah satu faktor yang mempengaruhi keberhasilan tanaman adalah penggunaan bibit yang berkualitas. Kualitas bibit dapat diketahui dari nilai indeks mutu bibit (IMB). Nilai IMB semakin tinggi menunjukkan kualitas bibit yang lebih baik.

Hasil dari penilaian bibit berdasarkan perlakuan disajikan pada Tabel 4. Perlakuan TC memberikan nilai berat kering, rasio pucuk akar dan indeks mutu bibit tertinggi, yaitu berturutturut sebesar 9,47 g; 1,72 dan 0,99 (malapari), dan sebesar 22,41 g; 8,96 dan 1,53 (nyamplung). Hal ini menunjukkan bahwa 
perbanyakan malapari dan nyamplung secara generatif akan menghasilkan bibit dengan kualitas paling baik di persemaian apabila menggunakan media TC yang merupakan campuran tanah + pupuk organik + Trichoderma spp. + mikoriza.

Tabel 4. Nilai kualitas bibit nyamplung dan malapari di persemaian

\begin{tabular}{lccc}
\hline \multicolumn{1}{c}{ Perlakuan } & $\begin{array}{c}\text { Berat Kering } \\
(g)\end{array}$ & Rasio pucuk dan akar & Indeks Mutu Bibit \\
\hline Malapari (P. pinnata) & & & \\
T & 2,32 & 1,08 & 0,27 \\
TK & 2,86 & 0,61 & 0,51 \\
TKM & 4,33 & 1,15 & 0,45 \\
TKT & 4,84 & 1,10 & 0,59 \\
TC & 9,47 & 1,72 & 0,99 \\
\hline Nyamplung (C. inophyllum) & & 1,90 & 0,55 \\
\hline T & 7,88 & 1,72 & 0,79 \\
TK & 9,19 & 2,01 & 1,45 \\
TKM & 21,90 & 1,40 & 1,57 \\
TKT & 17,32 & 8,96 & 1,53 \\
TC & 22,41 & & \\
\hline
\end{tabular}

Keterangan: $\mathrm{T}=$ tanah, $\mathrm{TK}=$ tanah+kompos, $\mathrm{TKM}=\operatorname{tanah}+$ kompos + mikoriza, $\mathrm{TKT}=\operatorname{tanah}+\mathrm{kompos}+$ Trichoderma spp., $\mathrm{TC}=$ tanah + kompos + mikoriza + Trichoderma $\mathrm{spp}$.

Tanaman memerlukan sumber nutrisi yang dipenuhi dengan adanya pupuk organik. Unsur hara yang ada di dalam pupuk organik akan semakin banyak dan mudah diserap oleh akar tanaman apabila dibantu oleh aktivitas mikoriza dan Trichoderma. Mikoriza berperan dalam peningkatan serapan unsur hara dan air, perbaikan nutrisi tanaman, dan meningkatkan ketahanan bibit terhadap kekeringan melalui mekanisme mempertahankan tekanan osmosis sel dan laju transpirasi (Suprapti et al., 2012). Trichoderma berfungsi memperbaiki kondisi tanah sekitar perakaran sehingga dapat meningkatkan produksi dan biomassa perakaran yang berfungsi untuk penyerapan air dan unsur hara (Tripathi et al., 2013). Pemberian Trichoderma spp. dan bahan organik akan meningkatkan serapan unsur nitrogen yang berfungsi untuk pembentukan bagian vegetatif seperti daun, akar dan batang serta klorofil yang akan meningkatkan proses fotosintesis. Proses fotosintesis yang meningkat akan meningkatkan hasil fotosintesis yang kemudian ditranlokasikan ke bagian vegetatif tanaman (Arnanda \& Ali, 2016). Pada akhirnya bibit yang diperoleh memiliki pertumbuhan paling optimal.

\section{KESIMPULAN}

Pengamatan sampai umur 6 bulan di persemaian menunjukkan bahwa perlakuan TC yang merupakan campuran pupuk organik + mikoriza + Trichoderma spp. merupakan media yang paling baik untuk peningkatan kualitas pertumbuhan bibit malapari dan nyamplung di persemaian.

\section{UCAPAN TERIMA KASIH}

Ucapan terima kasih disampaikan kepada bapak Rusdi dan Iwan Setiawan sebagai teknisi yang telah membantu selama pelaksanaan kegiatan penelitian.

\section{DAFTAR PUSTAKA}

Alimah, D. (2010). Budidaya dan potensi malapari (Pongamia pinnata L.) PIERRE sebagai tanaman penghasil bahan bakar nabati. Gelam, IV(2), 147-159.

Arnanda, M., \& Ali, M. (2016). Pertumbuhan bibit kelapa sawit yang diberi Trichokompos dengan frekuensi berbeda 
pada pembibitan utama. JOM Faperta, $3(2), 1-15$.

Arriagada, C., Aranda, E., Sampedro, I., GarciaRomera, I., \& Ocampo, J. A. (2009). Contribution of the saprobic fungi Trametes versicolor and Trichoderma harzianum and the arbuscular mycorrhizal fungi Glomus deserticola and $G$. claroideum to arsenic tolerance of Eucalyptus globulus. Bioresource Technology, 100(4), 6250-6257.

Charisma, A. M., Rahayu, Y. S., \& Isnawati. (2012). Pengaruh kombinasi kompos Trichoderma dan Mikoriza Arbuskular (MVA) terhadap pertumbuhan tanaman kedelai (Glycine $\max$ (L.) Merill) pada media tanam tanah kapur. Lentera Bio, 1(3), 111-116.

Danu, S. B., \& Putri, K. P. (2013). Model produksi benih malapari (Pongamia pinnata Merril.) Di Batukaras, Ciamis, Jawa Barat. Perbenihan Tanaman Hutan, 1(2), 61-69.

Dendang, B., \& Hani, A. (2014). Efektivitas Trichoderma spp. dan pupuk kompos terhadap pertumbuhan bibit sengon (Falcataria mollucana). Penelitian Agroforestry, 2(1), 13-19.

Dickson, A., Leaf, A. L., \& Hosner, J. F. (1960). Quality Appraisal Of White Spruce and White Pine Seedling Stock In Nurseries. The Forestry Chronicle, 36(1), 10-13.

Direktorat Jenderal Energi Baru, T. dan K. E. (2014). Energi Baru, Terbarukan dan Konservasi Potensi dan Peluang Investasi.

Dwitama, M. I., Nasib, M., Sitepu, O. C., Suandi, D. A. P., \& Simpen, I. N. (2016). Konversi minyak biji malapari (Pongamia pinnata L.) menjadi biodiesel melalui pemanfaatan katalis heterogen abu sekam padi termodifikasi. Journal of Chemistry, 10(2), 236-244.

Elviati, D., \& Siregar, E. B. M. (2010). Pemanfaatan Kompos Tandan Kosong Sawit Sebagai Campuran Media Tumbuh Dan Pemberian Mikoriza Pada Bibit Mindi (Melia azedarach L.). Jurnal Hidrolitan, 1(3), 11-19.

Hadi, W. A. (2009). Pemanfaatan Minyak Biji
Nyamplung (Calophyllum inophyllum L) sebagai Bahan Bakar Minyak Pengganti Solar. Jurnal Riset Daerah, 8(2), 10441052.

Hendromono. (2003). Kriteria penilaian mutu bibit alam waah yang siap tanam untuk rehabilitasi hutan dan lahan. Buletin Penelitian Dan Pengembangan Kehutanan, 4(1), 11-20.

Herliyana, E. N., Jamilah, R., Taniwiryono, D., \& Firmansyah, M. A. (2015). In-vitro Test of Biological Control by Trichoderma spp. Toward Ganoderma that attacked Sengon. Jurnal Silvikultur Tropika, 4(3), 190-195.

Kusuma, M. E. (2016). Efektivitas pemberian kompos Trichoderma sp terhadap pertumbuhan dan hasil rumput setaria (Setaria spachelata). Jurnal Ilmu Hewan Tropika, 5(2), 76-81.

Latifah, L., Hendrival, H., \& Mihram, M. (2014). Asosiasi Cendawan Antagonis Trichoderma harzianum Rifai dan Cendawan Mikoriza Arbuskular untuk Mengendalikan Penyakit Busuk Pangkal Batang pada Kedelai. Jurnal Hama dan Penyakit Tumbuhan Tropika. Jurnal Hama dan Penyakit Tumbuhan Tropika, 14(2), 160-169.

López-Bucio, J., Pelagio-Flores, R., \& HerreraEstrella, A. (2015). Trichoderma as biostimulant: exploiting the multilevel properties of a plant beneficial fungus. Scientia Horticulturae, 196, 109-123.

Mahdiannoor. (2012). Efektivitas Pemberian Trichoderma spp. dan Dosis Pupuk Kandang Kotoran Ayam Pada Lahan Rawa Lebak Terhadap Pertumbuhan dan Hasil Tanaman Kacang Panjang (Vignasinensis L.). Ziraa'ah, 33(1), 91-98.

Marbun, L., Yunasfi, Y., \& Mulya, M. B. (2015). Pemanfaatan fungi Aspergillus flavus, Aspergillus terreus, dan Trichoderma harzianum untuk meningkatkan pertumbuhan bibit Avicennia marina. Peronema Forestry Science Journal, 4(3), 192-198.

Nurbaity, A., Herdiyantoro, D., \& Mulyani, O. (2009). Pemanfaatan bahan organik sebagai bahan pembawa Inokulan fungi mikoriza arbuskula. Jurnal Biologi, 3(1), 7-11. 
Purwati, M. S. (2013). Respon pertumbuhan bibit kelapa sawit terhadap pemberian dolomit dan pupuk phospor. Ziraa'ah, 36(1), 25-31.

Ramesh, M. S., Birajdar, G. M., Tanaji, G. M., \& Bhale, U. N. (2017). Prevalence and Effect of Mycorrhizae on Growth of Pongamia pinnata Nursery Plant. Asian Journal of Plant Pathology, 11(11), 8994.

Roidah, I. S. (2013). Manfaat penggunaan pupuk organik untuk kesuburan tanah. Jurnal BONOROWO, 1(1), 30-42.

Sajimin, Y. C., Raharjo, N. D., Purwantari, \& Sutedi, E. (2007). Penggunaan probiotik pada kotoran domba sebagai pupuk organik untuk rumput benggala. Prosiding Seminar Nasional Teknologi Dan Veternier, 700-705.

Sari, A., Mardhiansyah, M., \& Sribudiani, E. (2014). Waktu potensial aplikasi mikoriza dan Trichoderma spp. pada medium gambut untuk meningkatkan pertumbuhan semai meranti tembaga (Shorea leprosula Miq.). PEST Tropical Journal, 2(1), 1-10.

Sugiyono, A. (2005). Pemanfaatan Biofuel dalam Penyediaan Energi Nasional Jangka Panjang. Seminar Teknologi Untuk Negeri, 78-86.
Suprapti, S., Santoso, E., Djarwanto, \& Turjaman, M. (2012). Pemanfaatan kompos kulit mangium untuk media pertumbuhan cendawan mikoriza arbuskula dan bibit Acacia mangium Willd. Jurnal Penelitian Hasil Hutan, 30(2), 114-123.

Syamsuwida, D., Putri, K. P., Kurniaty, R., \& Aminah, A. (2015). Seeds and Seedlings Production of Bioenergy Tree Species Malapari (Pongamia pinnata (L.) Pierre). Energy Procedia, 65, 67-75.

Tamin, R. P. (2016). Pertumbuhan semai jabon (Anthocephalus cadamba Roxb Miq.) pada media pasca penambangan batubara yang diperkaya fungi mikoriza arbuskula, limbah batubara dan pupuk NPK. Jurnal Penelitian Universitas Jambi, 18(1).

Tchameni, S. N., Ngonkeu, M. E. L., Begoude, B. A. D., Nana, L. W., Fokom, R., Owona, A. D., ... Kuaté, J. (2011). Effect of Trichoderma asperellum and arbuscular mycorrhizal fungi on cacao growth and resistance against black pod disease. Crop Protection, 30(10), 1321-1327.

Tripathi, P., Singh, P. C., Mishra, A., Chaunhan, P. S., Dwivedi, S., Bais, R. T., \& Tripathi, R. D. (2013). Trichoderma: a potential bioremediatior for environmental clean up. Clean Techn Environ Policy, 15, 541-550. 